\title{
Social Value Orientation on Corruption Prisoners
}

\author{
${ }^{1}$ AGUS MULYANA, ${ }^{2}$ AULIA ISKANDARSYAH, \\ ${ }^{3}$ AHMAD GIMMY PRATHAMA SISWADI, ${ }^{4}$ WILIS SRISAYEKTI \\ 1,2,3,4 Universitas Padjadjaran, Jl. Raya Bandung Sumedang KM. 21, Indonesia \\ 1 UIN Sunan Gunung Djati, Jl. AH. Nasution 105 Bandung, Indonesia \\ email: ${ }^{4}$ wilis_bandung@yahoo.com
}

\begin{abstract}
Social value orientation is a psychological factor that can influence cooperative behavior. In social values orientation, the prosocial type promotes cooperation while proself type is not. A social dilemma is a situation where to be cooperative or not. Corruption behavior is one of the contexts of social dilemmas. Someone who commits corruption means he/she shows non-cooperative behavior. It is hypothesized that someone who commits corruption is a self-type social values orientation because he/she prioritizes personal interests and is not cooperative. This study aims to explore how social value orientation types on corruption prisoners. Data collection in this study used a questionnaire distributed to participants and interview. The study found that not all corruptors are proself types and focused on personal interest. Individuals of prosocial types who focus on common interests can also commit corruption. Corruption perpetrators believe that anyone who is in their position will commit corruption. There is another psychological aspect that can encourage someone to commit corruption.
\end{abstract}

Keyword: corruption, social orientation, prisoners

\section{Introduction}

Psychological factor is a determinant to influence cooperative behaviour seeing that personality is more stable and shows static respond in facing a given situation. (Van Lange, Joireman, Parks, \& Van Dijk, 2013). One of psychological factors that may be considered to have influence and can, even more, predicts whether one will or will not carry cooperative action in social dilemma is social value orientation (Pletzer, Balliet, Joireman, Kuhlman, \& Voelpel, 2018; Van Lange et al., 2013). Social value orientation is an individual preference to value his and other results. (Balliet, Parks, \& Joireman, 2009). Van Lange et al., (2013) provides a definition to social value orientation as a desire to maximize the collective result and to optimize equality. Based on social value orientation, one can undertake action by considering personal and other necessity that will come up in giving priority to his own or the common interest.

Social value orientation is formed by personal experience in social interaction and relatively stable and constant (Van Lange et al., 2013). Social value orientation will affect to how action is taken by individual to solve his social dilemma (Wei, Zhao, \& Zheng, 2016). Besides, social value orientation could be decisive whether one can differentiate his and other results (Eek \& Gärling, 2008).

Van Lange, Otten, De Bruin, \& Joireman (1997) develops theory about social value orientation and classify it into three types: (1) prosocial that is a desire to maximize either his or her own result or other and to minimize result differences to both parties (equal); (2) individual that is a desire to maximize his or her own result with or without considering other result; and ( 3 ) competitive that is a desire to maximize his or her own result than other results and give more priority to personal interest. Thereafter, these types are reduced by combining individual and competitive into proself for their similarities to give priority to his personal interest (Van Prooijen, De Cremer, Van Beest, Ståhl, Van

Received: 2019-02-28, Revision: 2019-04-13, Accepted: 2019-05-29

Print ISSN: 0215-8175; Online ISSN: 2303-2499. DOI: http://dx.doi.org/10.29313/mimbar.v35i1.4479

Accredited $\mathbf{S 2}$ based on the decree No.10/E/KPT/2019 until 2024. Indexed by DOAJ, Sinta, Garuda, Crossreff, Dimensions 
Dijke, \& Van Lange, 2008). By doing so, there are two types of social value orientations namely prosocial to whom give priority to common interest and proself to whom giving priority to his personal interest.

Social value orientation can predict a possible action by those in social dilemma, where prosocial will show cooperative behaviour by giving priority to common interest, meanwhile proself will show contradictory (Van Lange et al., 1997). One with prosocial type, however, may show uncooperative action when he or she knows that other did the same, while the proself type will maximize his/her profit when he or she knows other people tend to carry cooperative actions (Sattler \& Kerr, 1991).

Previous researches on social value orientation show that one with prosocial type prone to show cooperative behaviour consistently and hoping other to do the same compare to proself type (De Cremer \& Van Lange, 2001; Sattler \& Kerr, 1991; Smeesters, Warlop, Van Avermaet, Corneille, \& Yzerbyt, 2003; Wei et al., 2016). Prosocial type shows cooperative behaviour for common interest, while the proself will be cooperative if it bring him/her more advantages (Stouten, De Cremer, \& Van Dijk, 2005).

In other research, social value orientation is a predictor factor to cooperative behaviour in social dilemma deal with charity (Van Lange, Bekkers, Schuyt, \& Van Vugt, 2007) and impact of transportation pollution to environment (Joireman, Van Lange \& Van Vugt, 2004). Grosch \& Rau (2017) found that dishonesty is much more conducted by an individualist social value tendency type. Beside, social orientation can predict how individual trustworthy during social dilemma.

Cooperative behavior is not an easy action to do as one can possibly give priority to his own interest than that common interest, mostly in the social dilemma. A social dilemma is a situation to ask for individual to choose between prioritising personal or common interest (Van Lange et al., 2013). When one gives priority to common interest, he or she is cooperative and when he or she gives priority to personal interest, it means he or she is uncooperative. Corruption is a form of social dilemma when clerk or official gives priority to personal interest ignoring moral value by receiving bribery (Chen, Jiang, \& Villeval, 2015).

Köbis, Van Prooijen, Righetti, \& Van
Lange (2016) classify corruption as form of uncooperative behaviour. Corruption can be means that one abuses his power to prioritize his or her personal interest. Meanwhile, to chose not to commit corruption means that he or she carry his/her responsible power out by giving priority to common interest. Definition of corruption, modestly and generally, is basically has similarities to abuse of power (Abidin \& Siswadi, 2015; Svensson, 2005; Köbis et al., 2016). Abidin \& Siswadi (2015) explains component in corruption; (1) corruption is a behaviour; (2) behaviour related to abuse of power and authority; (3) is done to gain personal and group interest; (4) by violating law or deviating from norm and moral value; and (5) happens or befalls in public office setting (government institutions) or private office setting (private corporations).

\begin{abstract}
Chen et al., (2015) explains that corruption in bribery is normally occurred in the institution for two reasons: the employee who can not refuse his personal preference to receive bribery and give opportunity and grant some project to the bribery giver and closes opportunities for other company to get the project and is uncoordinated to other official and commit to self corruption to avoid collective sanction. Corruptor basically knows his risk and sanction for what he had done, but his greedy and egoist to receive bribery is undeniable.
\end{abstract}

Criminal Law No. 311999 jo. Criminal Law No. 202001 and in Abidin \& Siswadi (2015) mentioned seven groups of corruption. First, state financial loss that is an action against law to enrich personal or other or corporation in which suffers state losses and economics. This type of criminality is committed not only by official government employee but also by business person. Second is bribery that is giving and promising something to official government employee in the purpose to get assistances and facilities. It is giving something to official government employee in relation to or because of responsibilities whether carrying out or not in his post. Bribery is usually to get facilities and access opposing to regular standard procedure. While receiving bribery is done to get economics profit or facilities from the bribery giver.

Third is forgery, a counterfeit to books and registers in administrative examination for official government employee in the purpose to self enrich or other. This corruption is administrative forgery in register and financial reports by official to get profit for him and other by law transgression. Forth is extortion that is asking someone by force to give or to pay or receive payment in discount and make him feel threatened and intimidated. In 
fact, the practice of asking both by force and moderate can cause one to give necessarily by reason of angst, inconvenience, and intimidated.

The fifth is deceiving by giving a fabricated payment and expenditure reports about some projects and marking up their number for personal or group interest. Yet, letting someone to commit deceiving is definitely deceiving oneself. Sixth is the conflict of interest in provision of goods that is taking partly or fully in purchasing, provisioning, and leasehold at the same time. This corruptive action is by designating family, friend and own enterprise without public auction (collusion and nepotism). The last group or seventh is gratification that is a wide range meaning of granting including money, goods, discount, reward, interest-free loan, travel ticket, hotel, tour, free medical care, and other facilities.

Corruption is a global problem. Each country fights massively against corruption. Not only Indonesia, other countries have also difficulties in solving corruption, especially for developed countries. Indonesia is not the worst index corruption level in the world due to many countries have lower corruption value index than ours. As too hard this corruption in the world is, United Nation decided 9 December as an international anti-corruption day commemorated annually. Indeed, there is an international survey institution that annually surveys a perception corruption index in each country and put it in ranking globally i.e Transparency International. It has its representative in each country and gives mark from 0 to 100 to corruption index. 0 means the highest level of corruption and 100 means definitely free from corruption. Among all countries around the world there is no single country that has 100 in mark. The highest mark in 2018 was Denmark with 88 out of 100 . Even New Zealand that in 2017 got 87 in its perception corruption index, decreased in the following year. It would be better to say that no single country in the world can claim absolutely free from corruption.

Then, how about Indonesia? As seen in table 1 , in the last 5 years, Indonesia raised its level from 34 in 2014 to 38 in 2018, adding 4 digit in its corruption index. This achievement was still insignificant seeing that we still in the lower average level as if 50 is middle mark of corruption level from 0 to 100 . As the increasing index value is still insignificant, government efforts to prevent corruption has been massively and seriously undertaken.

Table 1

Indonesia Corruption Perception Index

\begin{tabular}{lll}
\hline Year & Mark & Level \\
\hline 2014 & 34 & 107 out of 175 countries \\
2015 & 36 & 88 out of 168 countries \\
2016 & 37 & 90 out of 176 countries \\
2017 & 37 & 96 out of 180 countries \\
2018 & 38 & 89 out of 180 countries \\
\hline
\end{tabular}

Source: Transparency International, 2019

To take preventive action to corruption extension, in 2002 Indonesia government formed a special institution to eliminate corruption namely Komisi Pemberantas Korupsi (Eradication Corruption Commission), further called as KPK. However, the establishment of KPK by no means decreasing corruption in Indonesia. Indeed, in the last 5 years, corruption gets higher and higher as seen in Table 2. It gets wider and falls not only to the central but also to the lowest district government official.

Table 2

Corruption in Indonesia

\begin{tabular}{cccc}
\hline Year & Inspection & $\begin{array}{c}\text { Investi- } \\
\text { gation }\end{array}$ & $\begin{array}{c}\text { Prosecu- } \\
\text { tion }\end{array}$ \\
\hline 2014 & 80 & 56 & 50 \\
2015 & 87 & 57 & 62 \\
2016 & 96 & 99 & 76 \\
2017 & 123 & 121 & 103 \\
2018 & 164 & 199 & 151 \\
\hline
\end{tabular}

Source: Acch KPK, 2019

More and more years, corruption in Indonesia has been increasing. Does KPK performance get better to reveal corruption or its existence is still having no impact on decreasing corruption? It seems that eradicating corruption in Indonesia does not go in a positive direction, it even gets worse from year to year. Government efforts to reduce corruption are far from satisfactory.

KPK has three strategies in eradicating corruption: (1) repressive strategy is a law enforcement to bring corruptor to trial. In this strategy, steps to follow are inspection, investigation, prosecuting, and execution; (2) system improvement ascribed to condition where extant system possibly gives opportunities to corrupt; a good system 
have to prevent and minimizing corruption risk. A former system improvement by government included official government employee transparency by impelling them to enclose equity and property report; (3) education and campaign are learning and anti-corruption strategy to awake people's awareness about the impact of corruption, ask them to participate in eradicating corruption and anti corruption, as well as built a culture and anti corruption behaviour.

As we have seen, government strategy is ignoring human factor to corruption. If corruption is classified as individual uncooperative behavior, hence psychological factor becomes one determinant factor to influence him or her. One can give priority to personal interest in state of corruption by being non-cooperative and commit corruption. One's social value orientation can predict whether or not individual will cooperative.

As it is explained above, prosocial type of social value orientation is a person who gives priority to common interest and show cooperative behaviour. While proself type will be easily given priority to personal interest and show non-cooperative behaviour. Hence, corruption belongs to action that gives priority to personal interest than common interest. Based on this explanation, it can be presupposed that corruptor will have a proself social value orientation. It is because by committing corruption means that one gives priority to personal and individual interest than common and collective interest. This research is carried out to know what kind of orientation type the corruptor is, and whether corruptor in Indonesia has prosocial or proself social value orientation.

\section{Research Methodology}

This research is explorative to identify how social value orientation in sentenced corruptor ignoring how corruption is committed. Participants in this research consists of 50 men and are prisoner in (next will be called as WBP) from first class Sukamiskin prison as special prison for corruptor. Their average age is 47,9 old with the youngest is 18 old and the oldest is 66 year.

Data collection is taken when the prisoner follow routine briefing and direction in "Sanggar Pramuka" room at Sukamiskin prison room. After having permission to take data, researcher visited men who are officially in charge in that room. Furthermore, researcher coordinated with officials to ask them briefing and direction schedule. Data retrieval is done personally in face to face with WBP. Researcher was let the participant free to choose whether or not they fill the questioner. It has to be done to give them respect for their choice and in order to not offend research ethic.

The measurement of social value orientation type uses Triple Dominance of Social Values composed by Van Lange et al., (1997). This measuring instrument divides individual into three types of prosocial, individual, dan competitive. This measuring instrument is used more by many researchers to measure social value orientation such as (De Kwaadsteniet, Van Dijk, Wit, \& De Cremer, 2006; Van Lange, Klapwijk, \& Van Munster, 2011; Wei et al., 2016). In this measuring instrument, participants were to face a scenario to put in pair with the unfamiliar person to call him as anonymous. In the following step, the participants were asked to choose between $A, B$ or $C$ where number is put inside for him and the anonymous. His choice will credit a point for them as well as his partner. The more point they get, the better it is for them. In other words, the more is the better.

Sample of measure instrument is as follow: option A, for example, I get 450 and anonymous 450 . Option B is when I get 500 and anonymous get 350 . While option $C$ is when I get 450 and anonymous get 100 . If one chooses $A$, it means he belongs to prosocial type. Option $B$ is one of individual types, while option $\mathrm{C}$ is competitive type. The test consists of nine variations and categories that may be possible six times representing individual preference of prosocial, individual, and competitive. If there is no variation in item after six turns choosing, they belong to uncategorized (Van Lange et al., 1997). Individual belongs to individual type and competitive is classified into proself type (Van Prooijen et al., 2008).

This measurement instrument makes the participant possible to not to be categorized in prosocial type. Nine questions and conditions to put into category should have 6 similar types; when participants pick less than 6 given types, it means they could possibly belong to no-category. It can be said that they still have no orientation to face their social environment whether giving priority to common or personal interest. A 
categorized type is usually not revealed in research discussion considering that it is regarded to still have no preference behaviour to undertake in social dilemma.

Beside questioner, this research conducted interview to the participants. Question in interview relates to reasons and opportunities to commit corruption and how corruption befalls in those opportunities.

\section{Results And Discussion \\ Social Value Orientation Type}

From data retrieval, there are 17 WBP who have prosocial type, with 18 of them are proself type and 15 for non-category. Comparison between prosocial and proself type is not too high. In the table 3 , its can seen prosocial type is presented for $34 \%$, proself type is $36 \%$, and non-category is $30 \%$. It shows that social value orientation is not predominant factor to lead people to commit corruption. There are still other factors leading someone to commit corruption.

Table 3

Study Result

\begin{tabular}{lll}
\hline Type & Number & Percentage \\
\hline Prosocial & 17 & $34 \%$ \\
Proself & 18 & $36 \%$ \\
Uncategorized & 15 & $30 \%$ \\
Total & 50 & $100 \%$ \\
\hline
\end{tabular}

Corruption as non-cooperative behaviour in social dilemma means giving priority to personal interest rather than to common interest. In social value orientation, this describes the proself type and based on this approach it can be assumed that someone who commits corruption have proself type in his social value orientation. However, based on extant data on social value orientation type, all WBP is not completely proself. Number of prosocial type and proself is equally similar. To a greater extent, prosocial, proself, and non-category types are in equilibration in their value and merit as seen in figure 1.

Corruption behaviour by giving priority to personal interest describes that one prefers to not cooperative when facing social dilemma that gives him opportunity to commit corruption. For one with proself type, he commits to corruption because he prioritizes himself. However, for someone with prosocial type, he must give priority to common interest by committing no corruption. In fact, corruption is also possible to one with prosocial type.

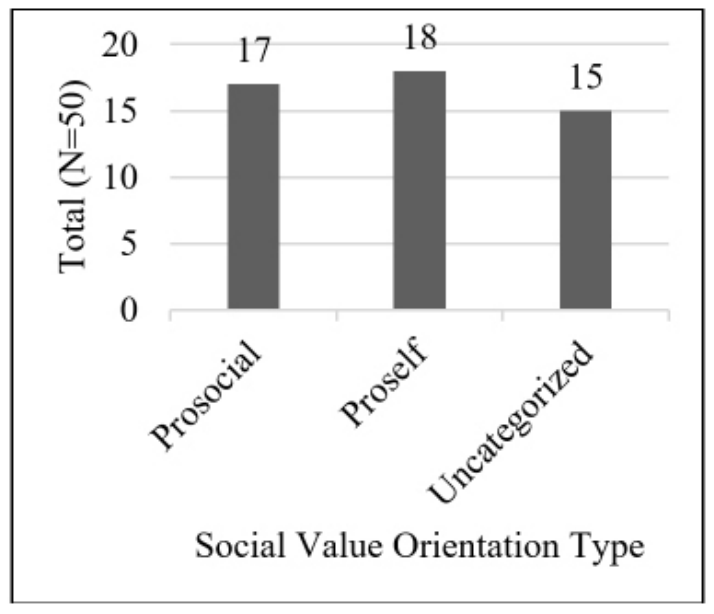

Figure 1. Comparative Result of Social Value Orientation Type

\section{Prosocial and Corruption}

Based on extant data, the explanation about prosocial type that is much more easy for being cooperative rather than the proself becomes a questionable in corruption conditions. When someone with prosocial type prefers to cooperative how possible is it for him to commit corruption as it is a form of non-cooperative behaviour? This is supported by the explanation that one with prosocial type will be possible to show cooperative behaviour when he knows his friend will not cooperative (Sattler and Kerr, 1991). This result corroborates the result of interview undertaken by researcher. This interview is not conducted to all participants. It relates to participant limited time to follow other activities in scout workshop. 5 voluntarily WBP being interviewed explained and confirmed that whoever in their position must have committed corruption and took this possible change to get maximum result. Regardless their corruption cases, they consider their action as something common done by man of business to get a job or project.

The result of this research is contradict to that by Attoma, Volintiru, \& Malezieux (2018) who dealing with social value orientation and dedication to pay tax. Despite the fact that the context is different between corruption and tax payment, however, both show how personal behaviour in dilemma whether to being cooperative by giving priority to common interest, paying tax, and not to 
commit corruption; or giving priority to self interest by not paying tax and commit corruption. In his research, Attoma et al. (2018) found that social value orientation became a factor that can affect the behaviour in dealing with tax payment. Individual with prosocial type is more obedient in paying tax than proself type. However, it is I different with this research result which states that both proself and prosocial types social value orientation still commit corruption.

Li, Yao, \& Ahlstrom (2014) explains that when one committed corruption by bribery, there is psychological process in his personal mind generating contradiction between social value and desire to fulfill personal necessity. Based on this explanation, if an individual with prosocial commits corruption, it is not possible he/she has internal conflict until he/ she finally decides to commit corruption. It is possible that, initially, he/she hesitates to commit corruption. However, with other factors surrounding him/her that lead him/ her to commit corruption, he/she does the corruption.

Inner conflict in individual facing opportunity to commit corruption could be won by cooperative behaviour, that is by committing no corruption and gives priority to common interest. In spite of the condition, it is common that corruption is committed in the absent of strong social norm, uncertain regulation, and social condition which please and accommodates corruption to take place (Li et al., 2014). In general, corruption is more easy to take place when opportunities to corrupt is frequently encountered. Apart from the research result, one involves more easily in committing corruption when a sudden opportunity appears than gradually and regularly, even in the time when corruptor knows and realizes that corruption is unethical to commit (Köbis, Van Prooijen, Righetti, \& Van Lange, 2015, 2017). One can commit to corrupt without intention and does not always start with simple action but directly jump into a big action when the opportunity to corrupt comes. For this reason, one with prosocial type can possibly does corruption when the opportunity comes and when he estimates his outcome is high-priced causing him to commit corruption.

In his research, Wei et al., (2016) explains that there would be a possibilities for individual to adjust with member of group's choice where he or she presides in prosocial decision. Social value orientation within individual mind can organize and influence how little or huge the effect of circumstances' pressure to imperative action in a given situation. One with prosocial type in social value orientation is prone to be resistant to social influence which giving priority to personal interest. One with prosocial type knows that act to give priority to personal interest is socially acceptable and refuse this option. Thus, one with proself will not follow majority decision not to give priority to personal interest (Wei et al., 2016). From this research, it can be seen that the role of group that significantly influence cooperative behaviour by prioritizing common interest will not be a challenge if members of group have similar commitment to give priority to common interest than personal interest. Group can drive the members to carry cooperative behaviour. Even one with proself type could give priority to common interest as if it is committed and compelled by group where he living at.

This research describes that corruptor is not merely giving priority to personal interest as observed from social value orientation theory. In fact, type of corrupter is equal between prosocial and proself. For this reason, there are other factors which can influence corruption beside social value orientation. Further research is suggested to explore other psychological factors inside the corruptor in order to get some conclusion about which psychological factor model of corruptor that leads him to commit corruption.

\section{Others Factor in Corruption}

There are other factors that can drive someone to commit corruption as noncooperative behaviour either psychological or non-psychological aspect. Rosiana, Djunaidi, Setyono, \& Srisayekti (2018) found that a reliance on corruption perpetrator's institution is classified as lower than one who did not commit corruption. Beside reliance on the institution, other psychological factors can affect to corruption, namely big five personalities and motivation (Abidin \& Siswadi, 2015). Even a group can drive its members to give priority to common interest rather than personal interest (Wei et al., 2016) to avoid corruption in that group.

When cooperative behaviour and corruption as non-cooperative behaviour are related, it is a situation that will affect one's cooperative behaviour in taking a decision in 
which an action will be taken.(Attari, Krantz, $\&$ Weber, 2014). Even reward and punishment that acceptable by one during his decision making will affect to whether he will show cooperative behaviour or not (Van Lange et al., 2011). In other side, learning model taken by individual can raises one's cooperative behaviour (Wibisono, Gusniarti, \& Nurtjahjo, 2016).

\section{Conclusions}

As far as known, this research is the first study to examine social value orientation on corruptors. This research is designed to explore how social value orientation in a sentenced corruptor ignoring his corruption cases and now is still serving his sentence in first-class prison of Sukamiskin Bandung. The result of this research shows that in committing corruption individual psychological factors, in this case social value orientation, is not the only factor to the individual to commit corruption. It is revealed from social value orientation type founded in corruptors that they belong not only to proself type but also to prosocial type with an equally similar number. Theoretically, corruption belongs to personal non-cooperative behaviour by giving priority to personal interest than to common interest and this reflects proself type of individual behaviour. However, one with prosocial type is still having possibilities to corrupt as long as he considers other people corrupt. This trust to other non-cooperative behaviour strengthens the impulse to corrupt for individual in the potential situation. Therefore, social value orientation is not a predominant factor in deciding people to commit corruption.

This study has succeeded in answer research question about social value orientation on corruptor. However, the researcher is aware of deficiency in this research. It is designed to only do the exploration research aiming at a solely acknowledge and reveal what type of social value orientation the corruptor is. Besides, aspect to be studied is still restricted to single variable and is not involved both psychological or non-psychological aspects. However, this research contribute the information that basically corruption perpetrator is not only influenced by individual factor or his internal. It is possible that external factor has a big role to impose individual to commit corruption. Hence, further research is still necessary in order to find other aspects of driving and supporting someone to commit corruption. It is expected that by understanding various aspects affecting the corruption, it would be easier to decrease and eliminate corruption in
Indonesia. The preventive action will be easier to do and corruption significantly decrease. Preventive strategy to corruption can be more variational and will not be limited only to extant KPK strategies by considering human aspect and psychological factor inside.

\section{References}

Abidin, Z. and Siswadi, A. G. P. (2015). Psikologi Korupsi. Bandung: Remaja Rosdakarya.

Attari, S. Z., Krantz, D. H., \& Weber, E. U. (2014). Reasons for cooperation and defection in real-world social dilemmas. Judgment and Decision Making, 9(4), 316-334.

Attoma, J. D., Volintiru, C., \& Malezieux, A. (2018). Gender, social value orientation, and tax compliance. CESifo Working Paper, No. 7372(November).

Balliet, D., Parks, C., \& Joireman, J. (2009). Social value orientation and cooperation in social dilemmas: A meta-analysis. Group Processes and Intergroup Relations, 12(4), 533-547. https://doi. org/10.1177/1368430209105040

Chen, Y., Jiang, S., \& Villeval, M. C. (2015). The tragedy of corruption : Corruption as a social dilemma. Groupe d'Analyse et de Théorie Economique Lyon St-Étienne (GATE Lyon St-Étienne) Working Papers, No. 1531 (Desember).

De Cremer, D., \& Van Lange, P. A. M. (2001). Why prosocials exhibit greater cooperation than proselfs: the roles of social responsibility and reciprocity. European Journal of Personality, 15(S1), S5-S18. https://doi. org/10.1002/per.418.abs

De Kwaadsteniet, E. W., Van Dijk, E., Wit, A., \& De Cremer, D. (2006). Social dilemmas as strong versus weak situations: Social value orientations and tacit coordination under resource size uncertainty. Journal of Experimental Social Psychology, 42(4), 509-516. https://doi.org/10.1016/j. jesp.2005.06.004

Eek, D., \& Gärling, T. (2008). A new look at the theory of social value orientations: Prosocials neither maximize joint outcome nor minimize outcome differences but prefer equal outcomes. New Issues and Paradigms in Research on Social Dilemmas, 10-26. https://doi.org/10.1007/978-0387-72596-3_2

Grosch, K., \& Rau, H. A. (2017). Gender differences in honesty: The role of social value orientation. Journal of Economic Psychology, 62, 258-267. https://doi. org/10.1016/j.joep.2017.07.008

Joireman, J. A., Van Lange, P. A. M., \& Van Vugt, M. (2004). Who cares about the environmental impact of cars?: Those with 
an eye toward the future. Environment and Behavior, 36(2), 187-206. https://doi. org/10.1177/0013916503251476

Köbis, N. C., Van Prooijen, J. W., Righetti, F., \& Van Lange, P. A. M. (2015). "Who doesn't?" - The impact of descriptive norms on corruption. PLOS ONE, 10(6). https:// doi.org/10.1371/journal.pone.0131830

Köbis, N. C., Van Prooijen, J. W., Righetti, F., \& Van Lange, P. A. M. (2016). Prospection in individual and interpersonal corruption dilemmas. Review of General Psychology, 20(1), 71-85. https://doi.org/10.1037/ gpr0000069

Köbis, N. C., Van Prooijen, J. W., Righetti, F., \& Van Lange, P. A. M. (2017). The road to bribery and corruption: Slippery slope or steep cliff? Psychological Science, 28(3), 297-306. https://doi. org/10.1177/0956797616682026

Komisi Pemberantasan Korupsi. (2019). Laporan Tahunan KPK. Available at: https://www.kpk.go.id/id/publikasi/ laporan-tahunan

Komisi Pemberantasan Korupsi. (2019). Rekapitulasi Tindak Pidana Korupsi. Avalaible at: https://acch.kpk.go.id/id/ statistik/tindak-pidana-korupsi

Li, Y., Yao, F. K., \& Ahlstrom, D. (2014). The social dilemma of bribery in emerging economies: A dynamic model of emotion, social value, and institutional uncertainty. Asia Pacific Journal of Management, 32(2), 311-334. https://doi.org/10.1007/ s10490-014-9406-8

Pletzer, J. A. N. L., Balliet, D., Joireman, J., Kuhlman, D. M., \& Voelpel, S. C. (2018). Social value orientation, expectations and cooperation in social dilemmas: A Metaanalysis. European Journal of Personality, 32, 62-83. https://doi.org/10.1002/ per.2139

Rosiana, D., Djunaidi, A., Setyono, I. L., \& Srisayekti, W. (2018). Social Experience and Trust: Studies on Prisoners and non-Prisoners. Mimbar: Jurnal Sosial dan Pembangunan, 34(2), 351-358. http://dx.doi.org/10.29313/mimbar. v34i2.3650.351-358

Sattler, D. N., \& Kerr, N. L. (1991). Might versus morality explored: Motivational and cognitive bases for social motives. Journal of Personality and Social Psychology, 60(5), 756-765. https://doi.org/10.1037/00223514.60.5.756

Smeesters, D., Warlop, L., Van Avermaet, E., Corneille, O., \& Yzerbyt, V. (2003). Do not prime hawks with doves: The interplay of construct activation and consistency of social value orientation on cooperative behavior. Journal of Personality and Social Psychology, 84(5), 972-987. https://doi. org/10.1037/0022-3514.84.5.972

Stouten, J., De Cremer, D., \& Van Dijk, E. (2005). All is well that ends well, at least for proselfs: Emotional reactions to equality violation as a function of social value orientation. European Journal of Social Psychology, 35(6), 767-783. https://doi. org/10.1002/ejsp.276

Svensson, J. (2005). Eight questions about corruption. Journal of Economic Perspectives, 19(3), 19-42. https://doi. org/10.1257/089533005774357860

Transparency International. (2019). Corruption Perception Index 2018. Available at: http://www.transparency.org

Van Lange, P. A. M., Bekkers, R., Schuyt, T. N. M., \& Van Vugt, M. (2007). From games to giving: Social value orientation predicts donations to noble causes. Basic and Applied Social Psychology, 29(4), 375-384. https:// doi.org/10.1080/01973530701665223

Van Lange, P. A. M., Joireman, J., Parks, C. D., \& Van Dijk, E. (2013). The psychology of social dilemmas: A review. Organizational Behavior and Human Decision Processes, 120(2), 125-141. https://doi. org/10.1016/j.obhdp.2012.11.003

Van Lange, P. A. M., Klapwijk, A., \& Van Munster, L. M. (2011). How the shadow of the future might promote cooperation. Group Processes and Intergroup Relations, 14(6), 857-870. https://doi. org/10.1177/1368430211402102

Van Lange, P. A. M., Otten, W., De Bruin, E. N. M., \& Joireman, J. A. (1997). Development of prosocial, indivdualistic, and competitive orientations: Theory and preliminary evidence. Journal of Personality and Social Psychology, 21(4), 273-292.

Van Prooijen, J. W., De Cremer, D., Van Beest, I., Ståhl, T., Dijke, M. van, \& Van Lange, P. A. M. (2008). The egocentric nature of procedural justice: Social value orientation as moderator of reactions to decision-making procedures. Journal of Experimental Social Psychology, 44(5), 1303-1315. https://doi.org/10.1016/j. jesp.2008.05.006

Wei, Z., Zhao, Z., \& Zheng, Y. (2016). Moderating effects of social value orientation on the effect of social influence in prosocial decisions. Frontiers in Psychology, 7, 1-9. https:// doi.org/10.3389/fpsyg.2016.00952

Wibisono, S., Gusniarti, U., \& Nurtjahjo, F. E. (2016). Pembelajaran kooperatif sebagai upaya meningkatkan motivasi, empati dan perilaku bekerjasama. SCHEMA - Journal of Psychological Research, 3(1), 1-10. 